\title{
PENGARUH KONSENTRASI SARI BUAH DAN JENIS GULA TERHADAP MUTU MINUMAN FUNGSIONAL DARI BENGKUANG (Pachyrhizus erosus)
}

\section{The Effect of Juice Concentration and Kind of Sugar on The Quality of Functional Beverages from Bengkuang (Pachyrhizus erosus)}

\author{
Kamsina \\ Balai Riset dan Standardisasi Industri Padang, \\ JI. Raya LIK No.23 Ulu Gadut Padang 25164 \\ e-mail: kamsinaina@gmail.com \\ Diterima: 17 Mei 2014, revisi akhir: 19 Mei 2014 dan disetujui untuk diterbitkan: 26 Mei 2014
}

\begin{abstract}
ABSTRAK
Sari buah bengkuang adalah sejenis minuman yang diperoleh dari bagian buah yang dapat dimakan melalui proses pencucian, penghancuran, dan penjernihan (jika dibutuhkan), dengan atau tanpa pasteurisasi dan dikemas untuk dapat dikonsumsi langsung. Sari buah bengkuang merupakan minuman fungsional karena selain rasanya yang menyegarkan, juga memberikan efek yang positif terhadap kesehatan, diantaranya sebagai obat demam, diabetes melitus dan kolesterol. Penelitian ini bertujuan untuk memberikan alternatif pengolahan bengkuang menjadi minuman fungsional. Rancangan penelitian menggunakan rancangan acak lengkap (RAL) secara faktorial untuk melihat pengaruh persentase sari buah bengkuang $(A)$ terdiri dari sari buah $100 \%$ (A1), sari buah $66 \%$ (A2), sari buah $33 \%(A 3)$, dan jenis gula (B) terdiri dari gula pasir (B1), gula batu (B2), gula Tropicana (B3). Hasil penelitian menunjukkan bahwa perlakuan konsentrasi sari buah bengkuang dan penambahan gula batu $150 \mathrm{~g} / \mathrm{l}$ (A1B2) memberikan hasil terbaik terhadap kadar inulin, total fenol, dan vitamin $\mathrm{C}$. Untuk semua perlakuan, cemaran mikroba Angka Lempeng Total dan kapang/khamir yaitu $<10$ koloni/g (0), Salmonella maupun bakteri koliform negative ( $<3 \mathrm{APM} / \mathrm{g}$ ), sedangkan cemaran logam $\mathrm{Pb}<0,0377 \mathrm{ppm}$ dan $\mathrm{Cu}<0,0153 \mathrm{ppm}$ lebih kecil dari limit of detection (LOD) serta memiliki ketahanan simpan selama 3 bulan penyimpanan pada kondisi suhu $5-10^{\circ} \mathrm{C}$.
\end{abstract}

\section{Kata Kunci : Bengkuang, sari buah, gula, minuman fungsional}

\begin{abstract}
Juice of bengkuang is a kind of beverage obtained from the edible part of a fruit through a process of washing, crushing and purification (if required), with or without pasteurization which is packaged to be consumed immediately. Bengkuang juice is a functional beverage because not only the taste is fresh but also gives a positive effect on health, such as drug fever, diabetes mellitus, and cholesterol. Purpose of the study to provide an alternative of bengkuang processing became a functional beverages and to increase the added value of bengkuang. The research design used a completely randomized design (CRD) in factorial to see effect of the percentage of bengkuang juice $(A)$ consisted of $100 \%$ juice $(A 1), 66 \%$ juice $(A 2), 33 \%$ juice $(A 3)$ and kind of sugars (B) consisted of granulated sugar (B1), cubes sugar (B2), Tropicana sugar (B3). The result showed that the treatment of bengkuang juice concentration and addition of cubes sugar $150 \mathrm{~g} / \mathrm{l}$ (A1B2) gave the best results based of inulin, total phenols, and vitamin C. For all treatments, microbial contamination of either Total Plate Count and molds/yeasts were < 10 colonies/g (0), Salmonella and coliform bacteria were negative $(<3$ APM/g), while the metal contaminant $\mathrm{Pb}<0.0377 \mathrm{ppm}$ and $\mathrm{Cu}<0.0153 \mathrm{ppm}$ were below the limit of detection (LOD) moreover had storage resistance for 3 months of storage at a temperature condition $5-10^{\circ} \mathrm{C}$.
\end{abstract}

Keywords: Bengkuang, juice, sugar, functional beverages 


\section{PENDAHULUAN}

Bengkuang (Pachyrhizus erosus) merupakan salah satu buah yang cukup besar potensinya di daerah Sumatera Barat, khususnya kota Padang, tersebar di beberapa kecamatan yaitu, Kecamatan Koto Tangah, Nanggalo, Kuranji, dan Pauh. Pada tahun 2005 areal tanam mencapai 130 ha dengan rata-rata produksi 192 kuintal per hektar dengan total produksi sebesar 2.765 ton (BPS, 2005). Besarnya produksi bengkuang menyebabkan kota Padang dikenal sebagai kota bengkuang dan dijadikan sebagai maskot kota Padang.

Bengkuang merupakan buah yang kaya akan berbagai zat gizi yang sangat penting untuk kesehatan terutama vitamin dan mineral. Vitamin yang terkandung dalam bengkuang yang paling tinggi adalah vitamin C.

Yeni, dkk (2013) menyatakan bahwa dengan bertambahnya umur tanaman menyebabkan kadar monosakarida menjadi berkurang atau pembentukan polisakarida sebagai komponen utama pati bertambah bersamaan dengan tingkat kematangan buah yang menyebabkan bertambah juga kandungan asam hidroksi karboksilat sebagai salah satu komponen aktif yang mempunyai sifat sebagai pembersih, pemutih dan pendingin pada kulit. Kandungan bahan yang dimiliki bengkuang seperti terlihat pada Tabel 1.

Tabel1. Komposisi kimia bengkuang per 100 gram umbi

\begin{tabular}{|l|l|c|c|}
\hline No. & \multicolumn{1}{|c|}{ Komponen } & Satuan & Kadar \\
\hline 1. & Kalori & Kal & 55 \\
2. & Kadar air & $\%$ & 82,38 \\
3. & Protein & $\%$ & 1,47 \\
4. & Lemak & $\%$ & 0,09 \\
5. & Karbohidrat & $\%$ & 9,72 \\
6. & Gula & $\%$ & 2,17 \\
7. & Gula non-pereduksi & $\%$ & 3,03 \\
8. & Serat & $\%$ & 0,64 \\
9. & Kadar abu & $\%$ & 0,50 \\
10 & Vitamin dan mineral & & \\
& $\bullet \quad$ Kalsium & $\mathrm{mg}$ & 16,0 \\
& $\bullet \quad$ Fosfor & $\mathrm{mg}$ & 18,0 \\
& $\bullet \quad$ Besi & $\mathrm{mg}$ & 1,13 \\
& $\bullet \quad$ Thiamin & $\mathrm{mg}$ & 0,5 \\
& $\bullet \quad$ Riboflavin & $\mathrm{mg}$ & 0,02 \\
& $\bullet \quad$ Niacin & $\mathrm{mg}$ & 0,2 \\
& $\bullet \quad$ Asam Askorbat & 14,0 \\
\hline
\end{tabular}

Sumber : Anonim (1996) dalam Yeni, dkk (2013)
Selain itu umbi bengkuang mengandung inulin yang bermanfaat bagi kesehatan dan dimanfaatkan dalam pangan fungsional. Inulin merupakan polimer dari unit-unit fruktosa. Inulin bersifat larut di dalam air, tidak dapat dicerna oleh enzimenzim pencernaan, tetapi difermentasi mikroflora kolon (usus besar). Oleh karena itu, inulin berfungsi sebagai prebiotik. Inulin telah dibuktikan secara klinis dapat meningkatkan bifidobakteria sehat di perut. Studi yang sama juga membuktikan bahwa inulin dapat membantu sistem daya tahan tubuh dan membantu penyerapan vitamin. (Bundaalf, 2011).

Pada dasarnya, minuman fungsional termasuk dalam salah satu jenis pangan fungsional. Sebagai pangan fungsional, minuman fungsional tentunya harus sudah memenuhi dua fungsi utama pangan yaitu memberikan asupan gizi pemuasan sensori seperti rasa yang enak dan tekstur yang baik, serta mempunyai fungsi nilai fungsionalnya seperti menjadi regulasi bioritme, sistem imunitas, sistem saraf dan pertahanan tubuh. Apabila minuman biasa menawarkan kebutuhan terhadap air dan sebagai pemuas rasa. Namun, khusus untuk minuman fungsional dilengkapi dengan fungsi tersier seperti probiotik, menambah asupan vitamin dan mineral tertentu, meningkatkan stamina tubuh dan mengurangi resiko penyakit tertentu (seperti: antioksidan untuk mengurangi resiko kanker) (Rezawidya, 2011).

Sari buah merupakan bagian dari minuman fungsional. Pangan fungsional harus berupa bahan pangan, bukan berupa pil atau kapsul, dan manfaatnya harus bisa dirasakan apabila dikonsumsi secara normal dalam bahan pangan. Dari sisi teknis, pangan fungsional dapat berupa: (1) Bahan pangan alami, (2) Bahan pangan yang telah ditambah komponen tertentu, (3) Bahan pangan yang telah dihilangkan kandungan komponen tertentu, (4) Bahan pangan yang fungsi biologis dari satu atau beberapa komponennya telah dimodifikasi, dan (5) Bahan pangan dengan kombinasi dari ciriciri tersebut diatas (Roberfroid, 2002).

Dalam pembuatan minuman sari buah selain buah, juga dibutuhkan pemakaian gula. Gula adalah suatu karbohidrat sederhana yang menjadi sumber energi 
dalam minuman sari buah. Gula paling banyak diperdagangkan dalam bentuk kristal sukrosa padat. Gula digunakan untuk mengubah rasa menjadi manis pada makanan atau minuman. Gula sederhana, seperti glukosa (yang diproduksi dari sukrosa dengan enzim atau hidrolisis asam), menyimpan energi yang akan digunakan oleh sel (Anonim, 2009).

Gula sebagai sukrosa diperoleh dari nira tebu, bit gula, atau aren. Meskipun demikian, terdapat sumber-sumber gula minor lainnya, seperti kelapa. Sumbersumber pemanis lain, seperti umbi dahlia, anggur, atau jagung, juga menghasilkan semacam gula/pemanis namun bukan tersusun dari sukrosa. Proses untuk menghasilkan gula mencakup tahap ekstrasi (pemerasan) diikuti dengan pemurnian melalui distilasi (penyulingan). (Suprayatmi, 1996)

Rasa manis yang biasa dijumpai pada tanaman terutama disebabkan oleh tiga jenis gula, yaitu sakarosa, fruktosa dan glukosa. Gula-gula ini berada secara sendirisendiri ataupun dalam bentuk campuran satu dengan yang lain.

Suprayatmi, (1996) menyatakan bahwa gula pasir atau disebut juga sebagai gula sukrosa merupakan gula yang terbuat dari sari tebu yang mengalami proses kristalisasi. Warnanya ada yang putih dan kecoklatan (raw sugar). Karena ukuran butirannya seperti pasir, gulajenis ini sering disebut gula pasir. Biasanya digunakan sebagai pemanis untuk masakan,minuman, kue atau penganan lain. Superindo, (2012) menambahkan bahwa gula batu adalah gula yang diperoleh dari pengolahan gula pasir biasa dengan tujuan agar mudah larut. Gula batu biasanya digunakan untuk minuman. Nutrifood (2013) menambahkan bahwa gula Tropicana Slim merupakan serangkaian produk sehat dan bercitarasa tinggi yang menginspirasi konsumen untuk hidup sehat lebih lama. Dengan kandungan yang memprioritaskan kesehatan dan memberikan manfaat-manfaat kesehatan seperti bebas gula dan rendah kalori.

Muchtadi (1977) menyatakan bahwa dalam pembuatan sari buah dibutuhkan bahan pemanis atau gula pasir sebanyak
$15 \%$. Selama ini belum ada minuman sari buah fungsional dari bengkuang kemasan dilakukan, oleh sebab itu maka perlu dilakukan penelitian "Pengaruh konsentrasi sari buah dan jenis gula terhadap mutu minuman fungsional" yang bertujuan untuk dapat memberikan alternatif pengolahan bengkuang menjadi minuman fungsional.

\section{METODOLOGI PENELITIAN}

Bahan yang diperlukan adalah bengkuang, gula pasir, gula batu, gula tropicana, kemasan botol kaca, aquadest, kain saring, lem label, bahan bakar serta bahan kimia untuk pengujian seperti Pepton Water, Potato Dextrose Agar, Plate Count Agar, Lactose Broth, Brilliant Green Lactose Broth dan Natrium Agar, $\mathrm{NaOH}$, methanol. Peralatan yang digunakan meliputi; neraca analitik, oven listrik, furnace, autoklaf, inkubator, laminar flow cabinet, AAS dan HPLC.

Rancangan yang dilakukan adalah Rancangan Acak Lengkap secara faktorial yakni konsentrasi sari buah (A) yaitu sari buah $100 \%$ (A1), sari buah $66 \%$ (A2), sari buah $33 \%$ (A3) dan jenis gula (B) terdiri dari gula pasir $150 \mathrm{~g} / \mathrm{L}$ (B1), gula batu $150 \mathrm{~g} / \mathrm{L}$ (B2), gula Tropicana 37,5 g/L (B3). Masingmasing perlakuan dilakukan dengan 3 kali ulangan. Proses pembuatan minuman fungsional bengkuang pada penelitian ini seperti terlihat pada Gambar 1.

Analisis kimia yang dilakukan terhadap produk sari buah bengkuang yakni kadar inulin, total fenol (metoda spetrofotometri UV-Vis) dan vitamin C (metoda iodometri), analisa mikrobiologi meliputi kapang/khamir, bakteri koliform dan Angka Lempeng Total, Escherichia coli dan Salmonella (SNI 19-2897-92, cemaran Mikroba). Sedangkan untuk cemaran logam, dilakukan analisis logam timbal $(\mathrm{Pb})$ dan tembaga $(\mathrm{Cu})$ menggunakan AAS.

Ketahanan simpan dilakukan terhadap pertumbuhan bakteri atau Angka Lempeng Total (ALT) dan kapang/khamir selama 3 bulan penyimpanan pada suhu 5 $10^{\circ} \mathrm{C}$ dalam refrigerator dengan kemasan botol kaca. 


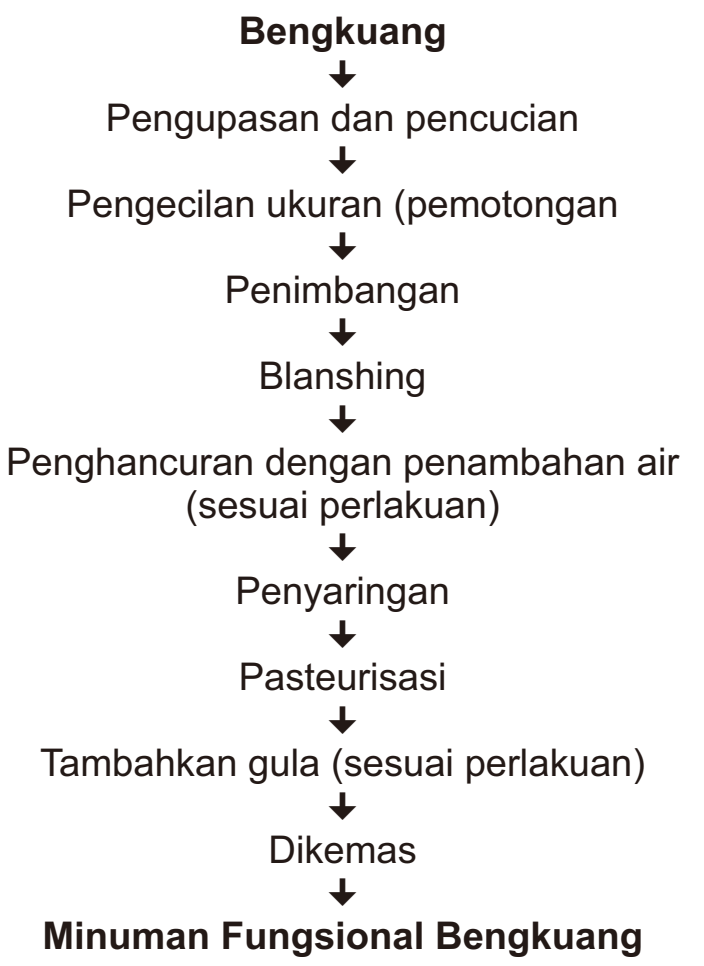

Gambar1. Diagram alir pembuatan minuman fungsional bengkuag

\section{HASIL DAN PEMBAHASAN}

\section{Kadar Inulin}

Perlakuan konsentrasi sari buah dan jenis gula memberikan hasil yang berpengaruh sangat nyata terhadap kadar inulin minuman fungsional. Untuk perlakuan variasi konsentrasi sari buah bengkuang berpengaruh sangat nyata terhadap inulin dari produk tetapi perlakuan jenis gula tidak berpengaruh.

Hasil analisis terhadap inulin minuman fungsional bengkuang menunjukkan bahwa variasi perlakuan konsentrasi sari buah $100 \%$ dan perlakuan penambahan gula batu $150 \mathrm{~g} / \mathrm{l}$ memberikan hasil tertinggi dengan kadar inulin 1,75\% (A1B2), tidak berbeda dengan perlakuan A1B1, tetapi berbeda nyata dengan perlakuan lainnya, sedangkan perlakuan A3B3 (konsentrasi sari buah 33\% dan penambahan gula tropicana $37,5 \%$ ) memberikan kadar inulin terendah yaitu $0,95 \%$ dan tidak berbeda nyata dengan perlakuan A3B1 dan A3B2. Hasil kadar inulin dapat dilihat pada Gambar 2.

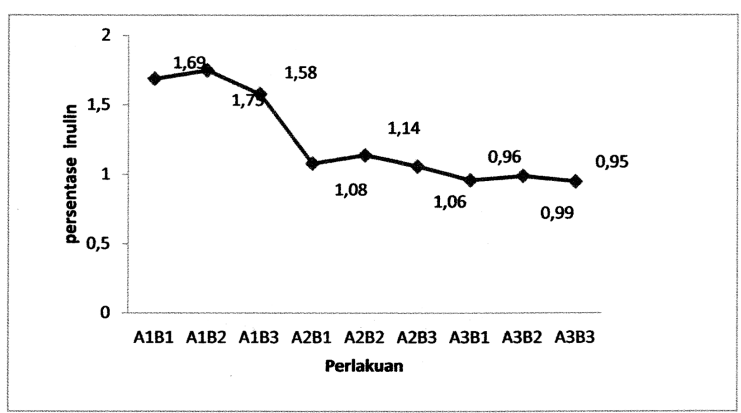

Gambar2. Hasil analisa kadar inulin minuman fungsional bengkuang

Hasil analisa yang dilakukan oleh Mulyani dkk (2011), menyatakan bahwa umbi bengkuang mengandung inulin sebesar $6,512 \%$ dan filtratnya $4,41 \%$. Kadar inulin pada umbi-umbian berkisar 0,14\%$14,54 \%$. Perbedaan ini dapat disebabkan perbedaan varietas, umur panen dan kondisi pertumbuhan.

Inulin adalah senyawa karbohidrat alamiah yang merupakan polimer dari unitunit fruktosa. Inulin sangat luas penggunaannya di dalam industri pangan, baik di Eropa, USA maupun Canada. Penggunaan inulin tersebut sebagai pengganti gula dan lemak yang menghasilkan kalori lebih rendah. Akhirakhir ini inulin digunakan sebagai komponen (ingredient) dari diet dan produk-produk rendah lemak (Toneli, et.al. 2008).

Sifat fungsional inulin sebagai serat makanan dapat larut (soluble dietary fiber) sangat bermanfaat bagi pencernaan dan kesehatan tubuh (Sardesai, 2003). Sifat penting lain dari inulin adalah sebagai serat makanan. Sifat ini berpengaruh pada fungsi usus dan perbaikan parameter lemak dalam darah. Inulin mempengaruhi fungsi usus dengan meningkatkan massa feses dan meningkatkan frekuensi defekasi terutama pada penderita konstipasi.

\section{Total Fenol}

Hasil analisa total fenol dari minuman fungsional bengkuang menunjukkan bahwa semua perlakuan berpengaruh sangat nyata terhadap kadar total fenol. Adapun hasilnya dapat dilihat pada Gambar 3. 


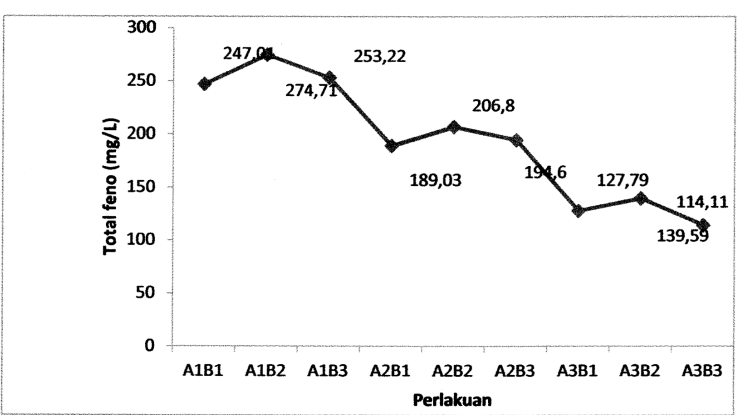

Gambar 3. Hasil analisa total fenol minuman fungsional bengkuang

Berdasarkan grafik pada Gambar 3 dapat dilihat bahwa kadar total fenol minuman fungsional dari bengkuang berkisar antara 114,11 - 247,01 mg/L). Total fenol tertinggi didapatkan pada perlakuan variasi perlakuan persentase sari buah $100 \%$ dan perlakuan penambahan gula batu $150 \mathrm{~g} / \mathrm{L}$ (A1B2) memberikan hasil tertinggi dengan total fenol memberikan hasil tertinggi dengan total fenol $274,71 \mathrm{mg} / \mathrm{L}$ dan berbeda sangat nyata dengan perlakuan lainnya, sedangkan total fenol terendah didapatkan pada perlakuan A3B3 dengan nilai 114,11 mg/L.

Senyawa fenolik berkontribusi pada keseluruhan kegiatan antioksidan tanaman terutama karena bersifat redoks. Mekanisme senyawa fenolik untuk aktivitas antioksidan dapat menetralisir radikal bebas lipid dan mencegah dekomposisi hidroperoksida menjadi radikal bebas (Javanmardi et al, 2003).

Lukitaningsih (2010) menyatakan, bahwa zat fenolik dalam bengkuang cukup efektif menghambat proses pembentukan melanin, sehingga pigmentasi akibat hormon, sinar matahari, dan bekas jerawat dapat dicegah dan dikurangi.

\section{Vitamin C}

Hasil analisis ragam menunjukkan bahwa perlakuan konsentrasi sari buah dan jenis gula berpengaruh sangat nyata terhadap vitamin $\mathrm{C}$ minuman fungsional bengkuang. Hasil analisis vitamin C (Gambar 4) terhadap minuman fungsional bengkuang yang dihasilkan pada tiap perlakuan menunjukkan rentang 11,96 $75,95 \mathrm{mg} / \mathrm{l}$. Nilai vitamin C tertinggi diperoleh pada perlakuan konsentrasi sari buah $100 \%$ dan penambahan gula batu $150 \mathrm{~g} / \mathrm{l}$ (A1B2) yaitu $75,95 \mathrm{mg} / \mathrm{l}$ berbeda nyata denga perlakuan lainnya, sedangkan nilai vitamin $C$ terendah diperoleh pada perlakuan A3B3 (konsentrasi sari buah 33\% dan penambahan gula tropicana $37,5 \%$ ). Kadar vitamin C pada masing-masing perlakuan dapat dilihat pada Gambar 4.

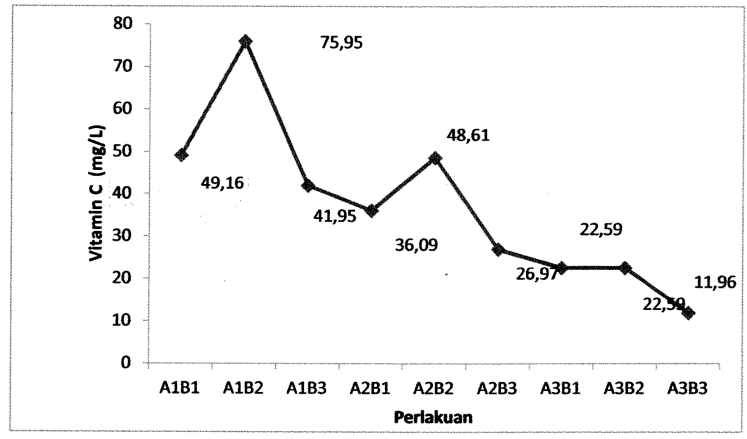

Gambar 4. Hasil analisa vitamin C sari buah fungsional bengkuang

Vitamin merupakan molekul organik yang sangat diperlukan tubuh untuk proses metabolisme dan pertumbuhan yang normal. Salah satu vitamin yang diperlukan oleh tubuh adalah vitamin C. Dari semua vitamin yang ada, vitamin C merupakan vitamin yang mudah rusak (Winarno, 2004). Agie (2007) menambahkan bahwa vitamin C merupakan senyawa kristal putih yang mudah larut dalam air, bukan asam karboksilat tetapi lakton, dan berikatan bersifat asam dan mudah teroksidasi dengan adanya pengelompokan enediol. vitamin ini berperan dalam mengendalikan infeksi dan respon tubuh terhadap stres. Senyawa ini juga merupakan antioksidan kuat yang dapat menetralkan radikal bebas berbahaya, membantu membuat kolagen, jaringan yang dibutuhkan untuk kesehatan tulang, gigi, gusi dan pembuluh darah serta juga membantu mencegah penyakit yang disebut penyakit kudis.

Dari hasil penelitian Lukitaningsih (2010) disebutkan bahwa bengkoang mengandung vitamin $\mathrm{C}$ dan flavonoid, yang merupakan tabir surya alami untuk mencegah kulit rusak oleh radikal bebas. Karenanya, hilirisasi produk bengkoang dapat bermanfaat untuk melembabkan dan mengencangkan kulit, memutihkan dan 
mencerahkan kulit serta berfungsi sebagai tabir surya (sun block) yang bisa mecegah terjadinya penuaan dini.

Berdasarkan Gambar 4, secara umum nilai vitamin $C$ minuman fungsional bengkuang pada masing-masing perlakuan mengalami penurunan seiring menurunnya konsentrasi sari buah. Hal ini dikarenakan vitamin $\mathrm{C}$ sangat larut di dalam air. Vitamin C juga mudah teroksidasi, dimana proses oksidasi tersebut dapat dipercepat oleh panas, sinar, alkali, enzim, oksidator serta oleh katalis tembaga dan besi. Vitamin sangat sensitif terhadap pemanasan, bahkan pemanasan yang tergolong ringan (sedikit diatas suhu kamar). Vitamin C juga mudah teroksidasi terutama bila terlarut dalam suatu pelarut, misalnya air (Widjanarko, 2008).

\section{Cemaran Logam}

Logam merupakan toksikan yang unik. Logam ditemukan dan menetap di alam tetapi bentuk kimianya dapat berubah akibat pengaruh fisikokimia, biologis, atau akibat aktivitas manusia. Logam-logam di alam ditemukan dalam bentuk persenyawaan dengan unsur lain dan sangat jarang ditemukan dalam elemen tunggal. Unsur ini dalam kondisi temperatur kamar tidak selalu berbentuk padat melainkan ada yang berbentuk cair, misalnya merkuri $(\mathrm{Hg})$. Dalam perairan, logam pada umumnya berada dalam bentuk ion-ion, baik sebagai pasangan ion ataupun dalam bentuk ion-ion tunggal (Lestari, 2010).

Dari hasil penelitian, dapat diketahui bahwa minuman sari buah fungsional bengkuang aman dari cemaran logam berat timbal $(\mathrm{Pb})$ dan tembaga $(\mathrm{Cu})$. Hasil pembacaan untuk kedua jenis logam ini kecil dari limit of detection (LOD). Hasil analisis cemaran logam $\mathrm{Pb}$ untuk semua perlakuan $<0,0377$ ppm dan $\mathrm{Cu}<0,0153$ ppm. Sesuai SNI 01-3719-1995 mengenai Minuman Sari Buah, syarat mutu logam $(\mathrm{Pb})$ adalah maksimal 0,3 ppm dan logam Cu adalah maksimal $5 \mathrm{ppm}$. Rendahnya nilai cemaran logam pada produk ini menunjukkan bahwa bahan-bahan dan alat-alat yang digunakan dalam pembuatan sari buah fungsional bebas dari kontaminasi logam berat, sehingga produk dapat dikategorikan memiliki kualitas yang baik.

\section{Mikrobiologi}

Pemeriksaan secara mikrobiologi untuk parameter uji Angka Lempeng Total, Kapang dan khamir untuk semua perlakuan menunjukkan hasil 0 koloni/gram $(<10)$, parameter Salmonella negatif, sedangkan untuk parameter bakteri Koliform, semua perlakuan hasilnya negatif $(<3)$. Hasil analisa mikrobologi semua perlakuan memenuhi SNI 01-3719-1995, dimana untuk ALT syarat mutunya maksimal $2 \times 10^{2}$ koloni/ml, kapang dan khamir maksimal 50 koloni/ml, Salmonella negatif dan bakteri Koliform maksimal 20 APM/ml. Rendahnya cemaran mikrobiologi yang didapat disebabkan karena terjaganya kebersihan (sanitasi) selama proses pengolahannya. Susiwi (2009) menyatakan bahwa peralatan yang terbuat dari kayu, batu atau plastik harus dibersihkan sebelum digunakan, harus dicuci dengan sabun bagian luar dan dalam, setelah dibilas sampai bersih dan tidak berbau semua alat ditiriskan. Program higiene dan sanitasi yang efektif merupakan kunci untuk pengontrolan pertumbuhan mikroba pada produk dan industri pengolahan makanan. Prinsip dasar sanitasi meliputi dua hal, yaitu membersihkan dan sanitasi. Menurut Fachruddin (1998), adanya mikroba dalam suatu produk makanan, akan dapat menyebabkan kerusakan pada makanan tersebut, dimana mikroba tersebut akan memanfaatkan pangan tersebut untuk metabolismenya yang dapat menyebabkan pengasaman dan pembusukan daripada makanan tersebut. Supardi dan Sukamto (1999) menambahkan adanya bakteri koliform menunjukkan adanya polusi kotoran pada air yang digunakan. Bahaya terbesar sehubungan dengan produk pangan adalah bila air yang digunakan untuk produk pangan tersebut telah tercemar oleh bahan buangan atau kotoran manusia atau hewan berdarah panas, karena dapat menyebabkan timbulnya penyakit demam usus atau disentri bila dikonsumsi. 


\section{Ketahanan Simpan}

Hasil analisa angka lempeng total minuman fungsional dari bengkuang akibat pengaruh konsentrasi sari buah bengkuang dan perlakuan jenis gula memberikan hasil yang berbeda seperti terlihat pada Gambar 5 .

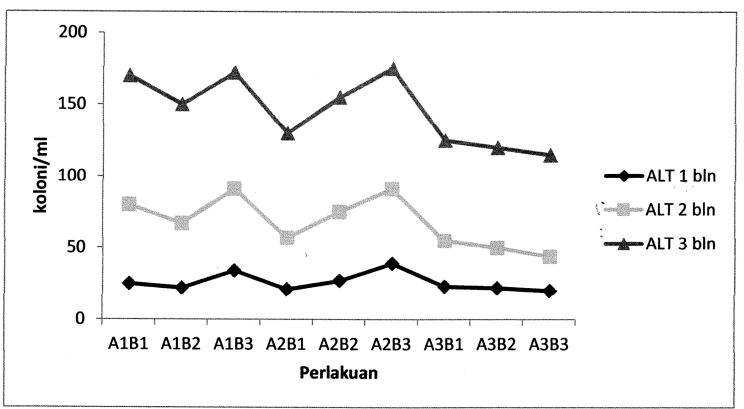

Gambar5. Hasil analisa ALT selama penyimpanan

Dari Gambar 5 dapat dilihat bahwa Angka lempeng total (ALT), kapang dan khamir minuman fungsional dari bengkuang selama penyimpanan menunjukkan terjadinya peningkatan, dimana nilai tertinggi didapatkan pada perlakuan penggunaan konsentrasi sari buah bengkuang $100 \%$ dan perlakuan penambahan gula tropicana $37,5 \mathrm{~g} / \mathrm{l}$ (A1B3) pada penyimpanan 3 (tiga) bulan dengan nilai 172 koloni/ml untuk ALT. Terjadinya kenaikan mikroba ini sejalan dengan bertambahnya waktu penyimpanan.

Sejalan dengan bertambahnya lama penyimpanan, pertumbuhan ALT juga mengalami peningkatan, sampai 3 (tiga) bulan penyimpanan sari buah fungsional dari bengkuang yang disimpan dalam refrigerator untuk semua perlakuan masih memenuhi standar SNI 01-3719-1995 (Minuman Sari Buah). Adapun persyaratan ALT untuk minuman sari buah adalah maksimal 200 koloni/ml. Menurut Winarno (2004) kemampuan mikroba untuk bertahan hidup dan berkembang berkaitan dengan faktor ekstrinsik diantaranya suhu, kelengasan udara, konsentrasi gas dalam lingkungan hidupnya.
Desrosier (1998) menambahkan, pengaruh atau hubungan antara kualitas produk dengan kondisi penyimpanan dipengaruhi oleh beberapa faktor yaitu jenis dan kualitas bahan baku yang digunakan seperti kadar air, zat gizi, metoda keefektifan pengolahan yang menyebabkan seluruh perubahan dalam aseptabilitas produk, jenis dan keadaan pengemasan dan juga pengaruh yang ditimbulkan oleh suhu dan kelembaban penyimpanan. Rahayu et al, (2003), menambahkan bahwa mutu produk pada saat baru diproduksi, dianggap dalam keadaan $100 \%$, dan akan menurun sejalan dengan lamanya penyimpanan atau distribusi. Selama penyimpanan dan distribusi, produk pangan akan mengalami kehilangan bobot, nilai pangan, mutu, nilai uang, daya tumbuh, dan kepercayaan.

\section{KESIMPULAN}

Berdasarkan hasil yang diperoleh dari penelitian pengaruh konsentrasi sari buah dan jenis gula terhadap mutu sari buah fungsional didapat kesimpulan bahwa perlakuan konsentrasi sari buah bengkuang dan jenis gula berpengaruh nyata terhadap kadar inulin, total fenol dan vitamin $\mathrm{C}$, tetapi berpengaruh tidak nyata terhadap logam berat Timbal $(\mathrm{Pb})$ dan Tembaga $(\mathrm{Cu})$ serta cemaran mikrobiologi minuman sari buah fungsional bengkuang.

Perlakuan konsentrasi sari buah bengkuang $100 \%$ dan penambahan gula batu $150 \mathrm{~g} / \mathrm{l}$ (A1B2) memberikan hasil terbaik terhadap kadar inulin, total fenol, dan vitamin C. Sari buah fungsional dari bengkuang dalam kemasan botol kaca yang disimpan dalam refrigerator, dapat memiliki ketahanan simpan 3 (tiga) bulan. Untuk semua perlakuan, cemaran kandungan mikrobanya, baik ALT, kapang/khamir yaitu $<10 \mathrm{koloni} / \mathrm{g}(0)$, Salmonella negatif maupun bakteri koliform negatif (<3 APM/g). 


\section{DAFTAR PUSTAKA}

Anonim. 1996. Daftar komposisi bahan makanan. Departemen Kesehatan RI.

Anonim. 2009. Pembuatan Minuman Sari Buah. Teknologi Pengolahan Pangan. (http://topagriculture. blogspot.com/2009/05/pembuatan-minuman-sari-buah.html).

Agie I. A. A . Izu and F.O . Izu agie. 2007. lodimetric determinationof ascorbic acid (Vitamin C) in citrus fruits. Research. Journal of Agr iculture and Biological Sciences, 3(5):367-369, 2007. (C2007, INSInet Publication. Department of Chemistry, Adeyemi College of Education, Ondo, Nigeria.

Badan Standardisasi Nasional. 1995. SNI No. 01-3719 - 1995. Minuman Sari Buah. Indonesia, Dewan Standardisasi Nasional, Jakarta.

Badan Pusat Statistik. 2005. Sumatera Barat dalam Angka. BPS. Sumatera Barat.

Bundaalf. 2011. Susu bengkoang prebiotik alami. Bundalf.htm.2011.

Desrosier, N.W. 1998. Teknologi pengawetan pangan. Penerbit Universitas Indonesia. Jakarta.

Fachruddin, L. 1998. Memilih dan memanfaatkan bahan tambahan makanan. Bogor. Trubus Agriwidya.

Javanmardi, J., Stushnoff, C., Locke, E. and Vivanco, J.M. 2003. Antioxidant activity and total phenolic content of Iranian Ocimum accessions. Food Chemistry 83: 547-550.

Lestari, S., 2010, Sifat dan karakteristik logam berat, http://srilestari.pdf /2010 /12/sifat-dan-karakteristik-logamberat.pdf. Diakses tanggal 9 Mei 2011.
Lukitaningsih. E, Ulrike H. 2010. Standarisasi ekstrak bengkoang sebagai bahan kosmetik pemutih kulit. Fakultas farmasi UGM. Yogyakarta.

Muchtadi, D. 1977. Pengetahuan dan pengolahan bahan nabati. Departemen Teknologi Hasil Pertanian IPB: Bogor.

Mulyani, Tri, Sudaryati dan Susanto A. 2011. Kajian peran susu skim dan bakteri asam laktat pada minuman sinbiotik umbi bengkuang (Pachyrrhizus erosus). E-jurnal Veteran vol.5 No.1. Jawa Timur.

Nutrifood. 2013. Gula rendah kalori dan gula nol kalori. http://www.tropicanaslim.com/tentang-tropicana-slim. Diakses tanggal 17 April 2014.

Rahayu WP, Nurwitri CC, Nuraida L, Hariyadi RT. 2003. Mikrobiologi pangan. Jurusan Teknologi Pangan dan Gizi, Fateta IPB.

Rezawidya 2011. Konsep minuman fungsional sebagai solusi cerdas membentuk masyarakat modern yang sehat. http://rewisa. wordpress .com/2011/05/02. diakses tanggal 24 September 2013.

Roberfroid MB. 2002. Functional foods: concepts and application to inulin and oligofructose. Universite Catholique de Louvain, Brussels, Belgium. roberfroid@pmnt.ucl.ac.be.

Sardesai, VM. 2003. Introduction to clinical nutrition. Ed ke-2. USA: Marcel Dekker, Inc on: Herb Panduan Hunters.

Supardi I, Sukamto. 1999. Mikrobiologi dalam pengolahan dan keamanan pangan. : Alumni Bandung .

Super Indo. 2013. Gula batu. http://www.superindo.co.id/resep dan tips/pengetahuan_produk. diakses tanggal 2 Januari $20 \overline{14}$. 
Suprayatmi, M. 1996. Yang manis tidak selalu manis. (http://pagihp.tripod. com/artikel3.htm). diakses tanggal 23 Oktober 2013.

Susiwi. 2009. Cara pengolahan pangan yang baik. Fakultas MIPA Universitas Pendidikan Indonesia. Tasikmalaya:

Toneli, J.T.C.L., K.J. Park, J.R.P. Ramalho, F.E.X. Murr dan I.M.D. Fabbro, 2008. Rheological Characterization of Chicory Root (Cichoriumintybus L.) Inulin Solution. Brazilian Journal of Chemical Engineering, Vol.25, No.03, 461-471. www.abeg.org.br/bjche; 5 Maret 2009.
Widjanarko SB. 2008. Karakteristik vitamin C. Dilihat tanggal 5 Mei 2013. <http:// simonbwidjanarko.wordpress.com>. Diakses tanggal 5 Mei 2013

Winarno, F.G: S.Fardiaz \& D.Fardiaz 1992. Pengantar teknologi pangan. PT. Gramedia Pustaka Utama. Jakarta.

Winarno, F.G. 2004. Kemanan pangan. MBrio Prees. Bogor.

Yeni, G; Failisnur dan Firdausni. 2013. Membuat aneka olahan bengkuang. IPB. Bogor. 